\title{
Ecology of Hydrozetes Berlese, 1902 (Acari, Oribatida) at various water bodies near Bydgoszcz (northern Poland)
}

\author{
ANNA SENICZAK \\ Department of Ecology, University of Technology and Life Sciences, Ks. Kordeckiego 20, \\ 85-225 Bydgoszcz, Poland; e-mail: aseniczak@utp.edu.pl
}

(Received on 21 May 2010; Accepted on 25 November 2011)

\begin{abstract}
Mites of the genus Hydrozetes Berlese, 1902 are abundant and important in wet habitats and can be useful in palaeoecological studies and bioindication. However, due to problems with their identification, there is still a limited knowledge on their ecology. In this study, 5 Hydrozetes species have been investigated. The most abundant was H. lemnae (about 121000 ind. $/ \mathrm{m}^{2}$ ), which constituted $76 \%$ of the total Oribatida at a pond shore in the Botanical Garden in Myślęcinek in Bydgoszcz. Its population density was lower in duckweed and filamentous algae on the water surface of the same pond. This species was found also in several other bodies of water, varying in water quality, but it preferred neutral $\mathrm{pH}$. Hydrozetes thienemanni had a narrower ecological tolerance and was restricted only to a forest pond with neutral $\mathrm{pH}$ in Pruszcz, where it dominated among the Oribatida. Three other species $-H$. lacustris, $H$. octosetosus, and $\mathrm{H}$. longisetosus - were found only in acid water. The last mentioned species was absent from the peat pond in Bagno Chlebowo Nature Reserve, with a high concentration of sulphur and worse oxygen conditions, but that site was suitable for $H$. lacustris.
\end{abstract}

Keywords: Hydrozetes, Acari, Oribatida, bog, Sphagnum, ecology

\section{INTRODUCTION}

The family Hydrozetidae Grandjean, 1954, includes one genus, Hydrozetes Berlese, 1902, with 30 species. They have a cosmopolitan distribution, except the Antarctic (SuBíAs 2004). In Europe and Poland, 7 species have recently been recorded (Seniczak et al. 2007, 2009; Seniczak \& Seniczak 2008), including a new one to science (SENICZAK \& SeniczaK 2009). All the species are aquatic, i.e. all their developmental stages live in water or at its margins (Schatz \& BehAn-Pelletier 2008), up to several meters under the water line (Buford 1976). This is possible due to many interesting adaptations of the species to aquatic life, like respiration through the plastron (KRANTZ \& BAKER 1982), orientation about the water depth thanks to a light-sensitive structure, the lenticulus (Alberti \& Fernandez 1988), and levitation (Newell 1945 ) that is known only in the adults (Behan-Pelletier \& EAmer 2007). 
All European species occur in lakes, ponds, and slowly flowing water (WEIGMANN 2006; Weigmann \& Deichsel 2006), where they can achieve high abundances (e.g. SENICZAK et al. 2006; SENICZAK 2011). Hydrozetes specimens have been found in many fossil samples and can be important in reconstruction of palaeoclimates (ERICKSON 1988; Krivolutsky et al. 1990; Solhøy \& Solhøy 2000; Solhøy 2001; ERICKson \& PlatT 2007). An increase in their density is correlated with water temperature, depth, and availability of nutrients in the aquatic ecosystem, while its low abundance or absence suggests a cold climate, with reduced nutrient cycling or prolonged dry conditions (ERICKSON \& PLATT 2007 and references therein). However, the poor knowledge of the ecology of Hydrozetes species limits their importance in both palaeoecological and bioindication studies.

This study aimed to compare the occurrence of Hydrozetes in selected bodies of water near Bydgoszcz and analyse ecological preferences of individual species.

\section{MATERIAL AND METHODS}

\section{Study area}

Samples were taken from the shores of 5 bodies of water: $\mathrm{My}=\mathrm{a}$ pond in the Botanical Garden in Myślęcinek in Bydgoszcz (5310'19” N, 1802'48” E, 83 m a.s.1.);

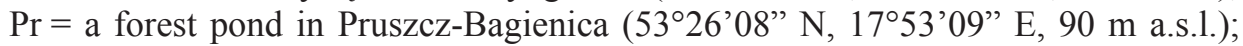
$\mathrm{Du}=\mathrm{a}$ pond in Dury Nature Reserve (53'38'20" N, $18^{\circ} 21^{\prime} 22^{\prime \prime} \mathrm{E}, 99 \mathrm{~m}$ a.s.1.); $\mathrm{Ma}=$

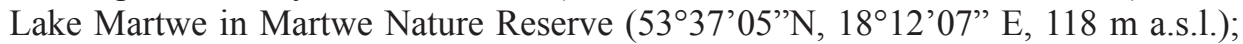
and $\mathrm{Ba}=$ a peat pond in Bagno Chlebowo Nature Reserve $\left(53^{\circ} 44^{\prime} 17^{\prime \prime} \mathrm{N}, 16^{\circ} 45^{\prime} 26^{\prime}\right.$ ' E, $65 \mathrm{~m}$ a.s.1.).

Pond My is under anthropogenic pressure (influence of the city, visitors, regular mowing of the lawn, and cutting of the shore plants). At its shore, the moss Cratoneuron filicinum Spruce dominated, and on the water surface, green filamentous algae and duckweed (mainly Lemna gibba L.) were present during the study. By contrast, all the other bodies of water are located in woodlands. At the shore of pond Pr there were mosses Pleurozium schreberi (Brid.) Mitt., Hylocomium splendens (Hedw.) and Pseudoscleropodium purum (Hedw.), while edges of the other ponds and the lake were dominated by Sphagnum mosses, mostly $S$. fallax (Klinggr.).

\section{Water analyses}

For the water analyses, $3 \mathrm{dm}^{3}$ of water were taken from each body of water at a distance of $2 \mathrm{~m}$ from the shore. The water was analysed in the Laboratory of Environmental Protection (Naftobazy Baza Paliw no. 2) in Nowa Wieś Wielka. The measured parameters and used methods are given in Table 1.

\section{Mite analyses}

From each shore, 10 samples of moss (each $100 \mathrm{~cm}^{2}$ in area and $5 \mathrm{~cm}$ deep) were taken in the summer of 2005 (My) or 2006 (Du, Ma, Ba) or in the autumn of 2005 (Pr). Additionally, from pond My, 10 samples $\left(500 \mathrm{~cm}^{3}\right)$ of green algae and 10 samples $\left(500 \mathrm{~cm}^{3}\right)$ of duckweed were collected from the water surface at a distance of $2 \mathrm{~m}$ from the shore. 
Table 1. Physicochemical parameters of the studied water bodies in northern Poland: My $=$ urban pond in Myślęcinek; $\mathrm{Pr}=$ forest pond in Pruszcz-Bagienica; $\mathrm{Du}=$ pond in Dury Nature Reserve; $\mathrm{Ma}=$ Lake Martwe in Martwe Nature Reserve; $\mathrm{Ba}=$ peat pond in Bagno Chlebowo Nature Reserve

\begin{tabular}{|c|c|c|c|c|c|c|c|}
\hline \multirow[t]{2}{*}{ Parameter } & \multirow[t]{2}{*}{ Method of analysis } & \multirow[t]{2}{*}{ Unit } & \multicolumn{5}{|c|}{ Body of water } \\
\hline & & & My & $\operatorname{Pr}$ & $\mathrm{Du}$ & $\mathrm{Ma}$ & $\mathrm{Ba}$ \\
\hline $\mathrm{pH}$ & $\begin{array}{l}\text { PH meter } \\
\text { PN-90 C-04540.01 }\end{array}$ & - & 7.2 & 7.8 & 5.8 & 5.7 & 5.2 \\
\hline Conductivity & PN-EN 27888:1999 & $\mu \mathrm{s} / \mathrm{cm}$ & 684 & 348 & 23 & 22 & 153 \\
\hline COD & $\mathrm{PN}-74 / \mathrm{C}-04578.03$ & $\mathrm{mgO}_{2} / \mathrm{dm}^{3}$ & 92 & 33 & 30 & 25 & 86 \\
\hline BOD5 & $\begin{array}{l}\text { PN-EN 1899-1:2002 } \\
\text { PN-EN 1899-2:2002 }\end{array}$ & $\mathrm{mgO}_{2} / \mathrm{dm}^{3}$ & 4.1 & 2.5 & 2.4 & 1.2 & 33 \\
\hline Chlorides & $\begin{array}{l}\text { PN-751C-04617.02 } \\
\text { PN ISO 9297:1994 }\end{array}$ & $\mathrm{mg} / \mathrm{dm}^{3}$ & 65 & 27 & 37 & 33 & 46 \\
\hline Sulphates & PN-74/C-04566.09 & $\mathrm{mg} / \mathrm{dm}^{3}$ & 91 & 35 & 3 & 1.8 & 12 \\
\hline $\begin{array}{l}\text { Total } \\
\text { phosphorus }\end{array}$ & $\begin{array}{l}\text { PN-88/C-04537/04 } \\
\text { PN EN 1189:2000 }\end{array}$ & $\mathrm{mg} / \mathrm{dm}^{3}$ & 0.09 & 0.13 & 0.02 & $<0.004$ & 0.03 \\
\hline
\end{tabular}

The mites were extracted using a modified Tullgren funnel. All Hydrozetes specimens were identified, including the juvenile stages, following SENICZAK et al. (2009). The populations were characterized with the abundance $(A)$, dominance $(D)$ and constancy $(C)$ indices, while the oribatid communities were characterized with the number of species $(S)$ and Shannon index $\left(H^{\prime}\right)$. The basic statistical analyses included the mean values, range, and standard deviation. For other statistical analyses, the values were log-transformed LN ( $\mathrm{x}+1)$ (Berthet \& Gerard 1965; McDonald 2009; ŁoMNICKI 2010). The normality of the distribution was tested with the Kolmogorov-Smirnov test, while the equality of variance in different samples, with the Levene test. When the assumption of normality or equality of variance was not met, the non-parametric Kruskal-Wallis test was used, followed by the Mann-Whitney $U$ test. The statistical calculations were carried out with STATISTICA 8.0 software.

\section{RESULTS}

Ponds My and Pr had a neutral $\mathrm{pH}$, high conductivity, and high phosphorus content, which indicate their eutrophication (Table 1). In contrast, pond Du and lake Ma were acidic and dystrophic, while peat pond $\mathrm{Ba}$ was acidic but had a high conductivity, and relatively high sulphur content.

The highest density of Hydrozetes was found in moss at the shore of pond My, but only H. lemnae (Coggi, 1897) was present there. Its density was about 121000 ind. per $\mathrm{m}^{2}$. Because of sample size $\left(100 \mathrm{~cm}^{2} \times 5 \mathrm{~cm}\right)$, this corresponds to 1210 ind. per $500 \mathrm{~cm}^{3}$. H. lemnae made up $76 \%$ of the total Oribatida at that site (Table 2). This 


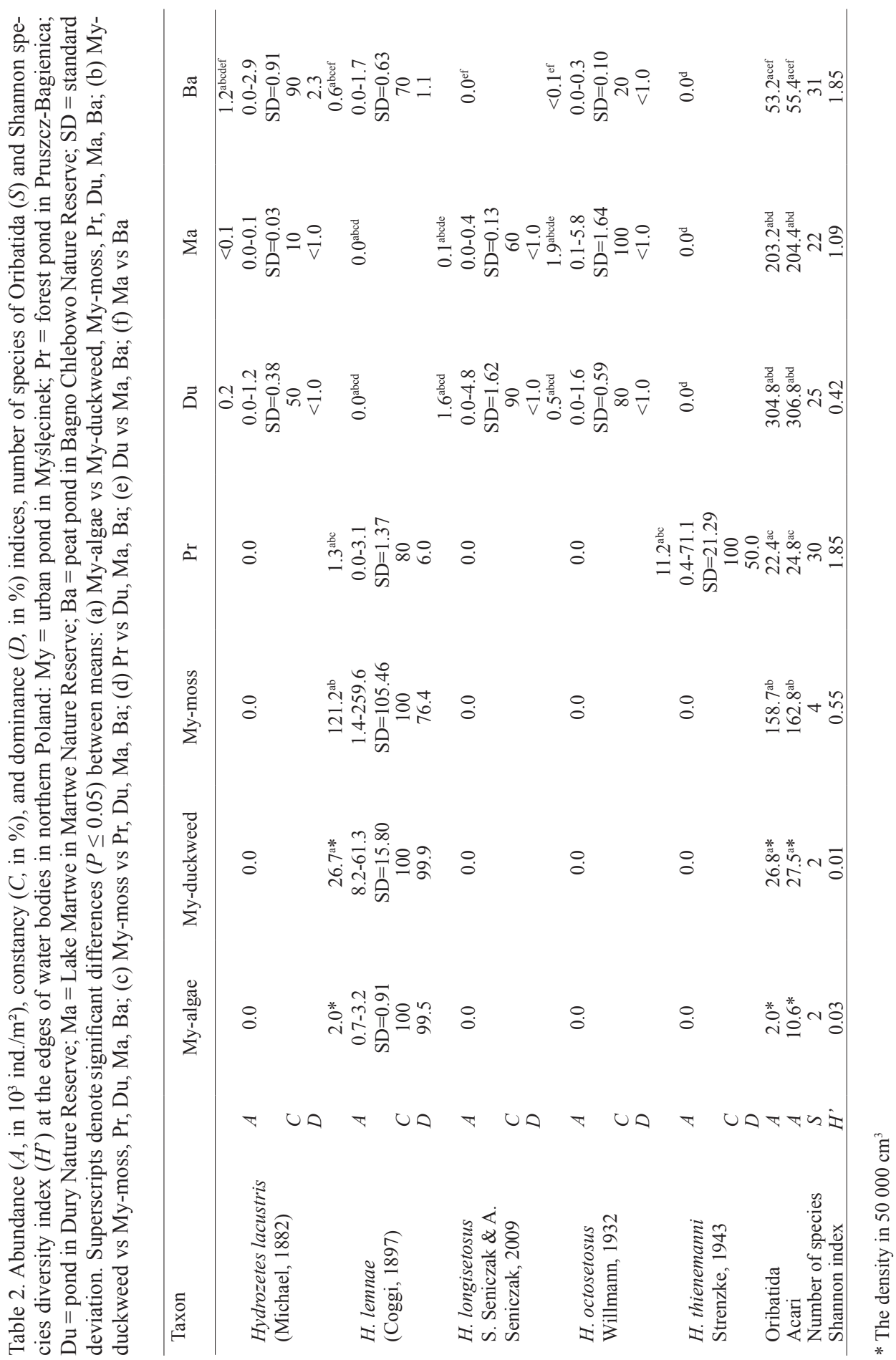


species was also present but less common on the water surface, where it was over 10 -fold more abundant in duckweed than in green algae. H. lemnae also occurred in pond $\mathrm{Pr}$ and in peat pond $\mathrm{Ba}$, but in far lower densities.

The second most abundant among Hydrozetes species was $H$. thienemanni Strenzke, 1943. It was present only in pond Pr, with the density of about 11000 ind. per $\mathrm{m}^{2}$ (corresponding to 110 ind. per $500 \mathrm{~cm}^{3}$ ). At the acidic pond Du and lake Ma, H. lacustris (Michael, 1882), H. longisetosus S. Seniczak \& A. Seniczak, 2009, and H. octosetosus Willmann, 1932 were present. However, at the former water body, the most abundant was $H$. longisetosus, while at the latter one, $H$. octosetosus. At peat pond $\mathrm{BC}$, only H. lacustris and H. octosetosus were found, and the first one dominated there.

\section{DISCUSSION}

Oribatid mites are abundant in aquatic and semi-aquatic habitats, including bogs, margins of lakes, and ponds (e.g. Belanger 1976; Fernandez \& Athias-Binche 1986; SENICZAK et al. 2006; SENICZAK 2011), where they decompose organic matter (KURIKI 2008). For example, H. lemnae on duckweed in Argentina had a mean population density of 1600 per $200 \mathrm{~cm}^{3}$ of water (FERNANDEZ \& ATHIAs-Binche 1986), which corresponds to 4000 per $500 \mathrm{~cm}^{3}$. In this study, the species achieved in the moss at pond My a 3-fold lower abundance, while on duckweed, its density was about 15-fold lower than in Argentina. In filamentous algae its abundance was 200-fold lower than in Argentina.

In the aquatic and semi-aquatic habitats, the species richness of Oribatida is lower than in soils (Schatz \& Behan-Pelletier 2008), but the Oribatida remains the most diverse group of mites (GERECKE et al. 2009).

Hydrozetes lemnae lives mainly in eutrophic water bodies (STRENZKE 1952), like lakes, ponds, and slowly flowing water, on submerged vegetation and on detritus (Weigmann \& Deichsel 2006). It was also found in a flooded pasture (HaArlov 1957), an oasis in Central Sahara (HAMmer 1975), aquariums with neutral pH (FAIN et al. 1988) and on the gills and throat epithelium of fish and other aquatic animals (GrandJEAn 1948; FAIN et al. 1988), but it was not a parasite (GrandJEAn 1949). Its feeding preferences and biology have been investigated by ATHIAS-BINCHE \& FERNANdez (1986), Fernandez \& Athias-Binche (1986) and Ermilov (2006).

Hydrozetes thienemanni has a similar ecology like $H$. lemnae and lives in eutrophic water bodies (STRENZKE 1952), but has a narrower ecological amplitude. In the present study this species was found exclusively in the forest pond Pr with neutral $\mathrm{pH}$, while $H$. lemnae occurred both at neutral and low $\mathrm{pH}$, but was more abundant at neutral $\mathrm{pH}$.

In contrast, H. lacustris was found only in acidic waters. Popp (1962) considered this species extremely euryionic, but other authors announced its preference for strongly acidic water (Walgram 1976; Weigmann 2006; Weigmann \& Deichsel 2006; Mistrzak et al. 2011), which is confirmed in this study. Similarly, H. octosetosus and $H$. longisetosus were found only in the bodies of water with low $\mathrm{pH}$, but $H$. longisetosus was absent in the peat pond $\mathrm{Ba}$, possibly due to the higher concentration 
of sulphur and worse oxygen conditions, in comparison to other water bodies. However, these conditions were favourable for H. lacustris, which achieved its highest density there, being accompanied by $H$. octosetosus.

\section{REFERENCES}

Alberti G., Fernandez N. A. 1988. Fine structure of a secondarily developed eye in a freshwater moss-mite, Hydrozetes lemnae (Coggi, 1899) (Acari: Oribatida). Protoplasma 146: 106-117.

Athias-Binche F., Fernandez N. A. 1986. Analyse demographique d'une population d'Hydrozetes lemnae Coggi, Acarien Oribate infeode a la lentille d'eau Lemna gibba L. en Argentine. 2. Les relations predateur/proie [Demographic analysis of a Hydrozetes lemnae Coggi population, oribatid mite depending on the duckweed Lemna gibba L. in Argentina. 2. Predator/prey relationships]. Zool. Jahrb. Syst. 113: 229-249 (in French).

Behan-Pelletier V. M., Eamer B. 2007. Aquatic Oribatida: adaptations, constraints, distribution and ecology. In: Acarology XI: Proceedings of the International Congress (Morales-MAlacara J. B., Behan-Pelletier V., Ueckermann E., Pérez T. M., Estrada-Venegas E. G., BADII M., Eds.), pp. 71-82, Instituto de Biología, Facultad de Ciencias, Universidad Nacional Autónoma de México; Sociedad Latinoamericana de Acarología, México.

Belanger S. D. 1976. The microarthropod community of Sphagnum moss with emphasis on the Oribatei. Unpubl. M. Sc. thesis. State University of New York, Syracuse, N. Y.

Berthet P., Gerard G. 1965. A statistical study of microdistribution of Oribatei (Acari). Part I. The distribution pattern. Oikos 16: 214-227.

Buford D. R. 1976. Morphology and life history of Hydrozetes bushnelli n. sp. (Oribatei, Hydrozetidae). Unpublished Ph.D. thesis, University of Colorado, Boulder.

ERICKSON J. M. 1988. Fossil oribatid mites as tools for Quaternary paleoecologists: Preservation quality, quantities, and taphonomy. In: Late Pleistocene and Early Holocene Paleoecology and Archaeology of the Eastern Great Lakes Region (Laub R. S., Miller N. G., Steadman D. W., Eds.), vol. 133, pp. 207-226, Bulletin of the Buffalo Society of Natural Sciences, Buffalo, NY.

Erickson J. M., Platt Jr. R. B. 2007. Oribatid Mite Studies. In: Encyclopedia of Quaternary Science (Scott Elias, Ed.), pp. 1547-1566, Elsevier, London.

Ermilov S. G. 2006. The life cycle of Hydrozetes lemnae (Oribatei, Hydrozetidae). Ent. Rev. 86, Suppl. 2: 177-181.

Fain A., Lambrechts L., Wauthy G. 1988. Observations on the acarofauna of fish-aquariums. III. Presence of Hydrozetes lemnae (Coggi, 1899) (Cryptostigmata) in aquariums in Belgium. Bull. Ann. Soc. R. Entomol. Belg. Entomol. 124: 255-256.

Fernandez N. A., Athias-Binche F. 1986. Analyse démographique d'une population d' Hydrozetes lemnae Coggi, acarien oribate inféodé à la lentille d'eau Lemna gibba L. en Argentine. 1. Méthodes et techniques, démographique d'H. lemnae, comparaisons avec d'autres oribates [Demographic analysis of a Hydrozetes lemnae Coggi population, oribatid mite depending on the duckweed Lemna gibba L. in Argentina. 1. Methods and techniques, demographic assessments of Hydrozetes lemnae, comparisons with other Oribatida]. Zool. Jahrb. Abt. Syst. Oekol. Geogr. Tiere 113: 213-228 (in French).

Gerecke R., Schatz H., Wohltmann A. 2009. The mites (Chelicerata: Acari) of the CRENODAT project: faunistic records and ecological data from springs in the autonomous province of Trento (Italian Alps). Int. J. Acarol. 35: 303-333.

Grandjean F. 1948. Sur les Hydrozetes (Acariens) de l'Europe occidentale [About Hydrozetes (Acariens) of the Western Europe]. Bull. Mus. nat. Hist. natur. (2), 20: 328-335 (in French). 
Grandjean F. 1949. Sur le genre Hydrozetes Berl. (Acariens) [About the genus Hydrozetes Berl. (Acari)]. Bull. Mus. nat. Hist. natur. (2), 21: 224-231 (in French).

HaArlov N. 1957. Microarthropods from Danish soils: Systematics. Spol. Zool. Mus. Hauniensis 17: $1-60$.

Hammer M. 1975. On some Oribatids from Central Sahara (Acari, Oribatidae). Steenstrupia 3: 187-196.

KRANTZ G. W., BaKer G. T. 1982. Observations on the plastron mechanism of Hydrozetes sp. (Acari: Oribatida: Hydrozetidae). Acarologia 23: 273-277.

Krivolutsky D. A., Druk A. Ja., Eitminaviciute I. S., Laskova L. M., Karppinen E. 1990. Fossil oribatid mites. Mokslas Publ., Vilnius.

KURIKI G. 2008. The life cycle of Limnozetes ciliatus (Schrank, 1803) (Acari: Oribatida). J. Acarol. Soc. Jpn. 17: 75-85.

ŁomNICKI A. 2010. Wprowadzenie do statystyki dla przyrodników [Introduction to statistics for the biologists]. PWN, Warszawa (in Polish).

McDonald J. H. 2009. Handbook of Biological Statistics, 2nd ed. Sparky House Publishing, Baltimore, Maryland.

Mistrzak M., Seniczak A., Seniczak S. 2011. Hydrozetes species (Acari, Oribatida) at bog ponds and pools in the Tatra National Park and Orawa-Nowy-Targ Basin (Kotlina Orawsko-Nowotarska) in southern Poland. Biological Lett. 48: 139-145.

Newell I. M. 1945. Hydrozetes Berlese (Acari, Oribatoidea): the occurrence of the genus in North America and the phenomenon of levitation. Trans. Conn. Acad. Arts Sci. 36: 253-275.

Popp E. 1962. Semiaquatile Lebensräume (Bülten) in Hoch- und Niedermooren. (2. Teil: Die Milbenfauna) [Semi-aquatic habitats (hummocks) of peatbogs and fens. (Part 2. The mite fauna)]. Int. Rev. ges. Hydrobiol. 47: 533-579 (in German).

Schatz H., Behan-Pelletier V. M. 2008. Global diversity of oribatids (Oribatida: Acari: Arachnida). Hydrobiologia 595: 323-28.

SenicZaK A. 2011. Seasonal dynamics of oribatid mites (Acari, Oribatida) at the lake Jeziorko Kozie, in Tuchola Forest, Poland. Biological Lett. 48: 3-11.

SenicZaK A., SEnicZAK S. 2008. Setal variability of Hydrozetes lemnae (Coggi, 1897) and H. thienemanni Strenzke, 1943 (Acari: Oribatida: Hydrozetidae). Biologia 63: 677-683.

Seniczak A., Seniczak S., Nowicka A. 2006. Roztocze (Acari) strefy brzegowej dwóch jezior śródleśnych o różnej jakości wody, w Borach Tucholskich [The mites (Acari) of the water edge of two forest ponds with different water quality in the Tuchola Forest]. Zootechnika 36: 31-38 (in Polish).

Seniczak S., Norton R. A., Seniczak A. 2009. Morphology of Hydrozetes confervae (Schrank, 1781) and H. parisiensis Grandjean, 1948 (Acari: Oribatida: Hydrozetidae), and keys to European species of Hydrozetes Berlese, 1902. Zool. Anz. 248: 71-83.

Seniczak S., Seniczak A. 2009. Hydrozetes longisetosus sp. nov. (Acari: Oribatida: Hydrozetidae) - the most primitive European species of Hydrozetes from Poland. J. Nat. Hist. 43: 951-971.

Seniczak S., Solhøy T., SeniczaK A. 2007. Systematic status of Hydrozetes octosetosus Willmann, 1932 (Acari: Oribatida: Hydrozetidae) in the light of ontogenetic and ecological studies. J. Nat. Hist. 41: 2081-2098.

Solnøy I. W., Solnøy T. 2000. The fossil oribatid mite fauna (Acari, Oribatida) in late glacial and early Holocene sediments in Kråkenes Lake, Western Norway. J. Paleolimnol. 23: 35-47.

Solnøу T. 2001. Oribatid mites. In: Tracking environmental change using lake sediments. Zoological Indicators (Smol J. P., Birks J. B., Last W. M., Eds.), vol. 4, pp. 81-104, Kluwer Academic Publishers, Dordrecht, The Netherlands.

StrenzKe K. 1952. Untersuchungen über die Tiergemeinschaften des Bodens: Die Oribatiden und ihre Synusien in den Böden Norddeutschlands [Studies on the animal communities of the soil. The oribatid mites and their synusia in the soils of northern Germany]. Zoologica, Stuttgart 104: 1-173 (in German). 
SuBÍAS L. S. 2004. Listado sistemático, sinonímico y biogeográfico de los Ácaros Oribátidos (Acariformes, Oribatida) del mundo (1748-2002) [The list of the systematics, synonyms and biogeography of the oribatid mites (Acariformes, Oribatida) of the world (1748-2002)]. Graellsia 60: 3-305 (in Spanish).

WALGRAM M. 1976. Über die Verbreitung der wasserbewohnenden Hornmilbengattung Hydrozetes Berlese 1902 (Acari, Oribatei) in Österreich [About the distribution of aquatic oribatid species Hydrozetes Berlese 1902 (Acari, Oribatei) in Austria]. Mitt. Naturwiss. Vereins Steiermark 106: 215-219 (in German).

Weigmann G. 2006. Hornmilben (Oribatida) [Oribatid mites (Oribatida)]. Die Tierwelt Deutschlands, vol. 76, Goecke. \& Evers, Keltern (in German).

Weigmann G., Deichsel R. 2006. 4. Acari: Limnic Oribatida. In: Süßwasserfauna von Mitteleuropa, 7/2-1 (Brauer A., Ed.), pp. 89-112, Elsevier, Spektrum Akademischer Verlag. 